\title{
Application of the Farm Simulation Model approach on economic loss estimation due to Coronavirus (COVID-19) in Bangladesh dairy farms-strategies, options, and way forward
}

\author{
Mohammad Mohi Uddin $^{1} \cdot$ Amrin Akter $^{1}$ - A. B. M. Khaleduzzaman ${ }^{2} \cdot$ Mst. Nadira Sultana $^{1} \cdot$ Torsten Hemme $^{3}$
}

Received: 21 May 2020 / Accepted: 29 October 2020 / Published online: 23 November 2020

(C) Springer Nature B.V. 2020

\begin{abstract}
The objective of this paper is to quantify the economic loss of the dairy farms due to the pandemic novel Coronavirus (COVID19) infection by analyzing the real-time data of two typical farms (BD-2 and BD-14 cow) in Bangladesh and propose a strategic plan of action to make policy decisions in order to support the dairy industry. The International Farm Comparison Network (IFCN) Farm Simulation Approach and Technology Impact Policy Impact Calculations (TIPICAL) model was used considering with Corona (WC) and without Corona (WOC). The Integrated Dairy Research Network (IDRN) database (January 2019 to July 2020) was used for simulation of IFCN two typical farms. The milk price is decreased by $17 \%$ and feed price is increased by $3.7 \%$ due to COVID-19 in March which was used as the base for farm simulation. This resulted in a decrease in milk yield by $7.9 \%$ and $8.9 \%$ for small household and family farms, respectively. The cost of milk production increased by $19.10 \%$ and $10.9 \%$ for household and family farms, respectively. This has an overall negative impact on farm income which accounted for national economic loss from dairy farms in Bangladesh to 4.43 million USD/day (36.84 crore BDT). This loss has been fluctuated from April onward and was higher in June (3.83 million USD/day) due to a combination of COVID-19, flood, and seasonality effect on lowering milk production. At the same time, the farmers' response to the resilience capacity (liquidity, operating profit margin, and financial performance) to combat COVID-19-induced situation has been declined substantially. Based on this, we conclude that the government might take a strategy to support farmers by providing financial support for increasing the operating capital and decreasing the cost of milk production. The outcome of this study is expected to be beneficial for policymakers, farmers, and processors in Bangladesh and similar other countries elsewhere.
\end{abstract}

Keywords Action plan · COVID-19 $\cdot$ Cost of milk production $\cdot$ Economic loss $\cdot$ Farm income $\cdot$ Farm resilience

Mohammad Mohi Uddin

mohamamd.uddin@bau.edu.bd

Amrin Akter

amrin42140@bau.edu.bd

A. B. M. Khaleduzzaman

abmk5566@gmail.com

Mst. Nadira Sultana

nadira_bau@yahoo.com

Torsten Hemme

torsten.hemme@ifcndairy.org
Integrated Dairy Research Network (IDRN), Department of Animal Nutrition, Bangladesh Agricultural University, Mymensingh 2202, Bangladesh

2 Department of Livestock Services (DLS), Ministry of Fisheries and Livestock, Government of the People's Republic of Bangladesh, Dhaka, Bangladesh

3 International Farm Comparison Network (IFCN) Dairy Research Center, University of Kiel, Schauenburger Str. 116, 24118 Kiel, Germany 


\section{Introduction}

In 2019, milk production in Bangladesh is 10.47 million $^{1}$ tons (DLS 2019) but according to the Integrated Dairy Research Network (IDRN), milk production is estimated as 8.14 million tons (IDRN 2020). With the demand in milk production, Bangladesh needs at least another 10 years to be self-sufficient. Milk production in 2030 will be 18.1 million tons (as revealed from the ARIMA model) and the demand will be 17.22 million tons (DLS 2019). Milk self-sufficiency in Bangladesh in 2030 will be $106 \%$ as per the Department of Livestock Services (DLS) data while the same will be $80 \%$ as per IDRN data (Uddin et al. 2020a, b). While Bangladesh dairy has been trying to overcome the loss incurred from the milk quality shock during the second half of the year 2019, the sudden infection of pandemic novel Coronavirus (COVID-19) leads the dairy farming in Bangladesh into a further deep crisis. Apart from the economic loss, the dairy farmers fall under other threedimensional problems: (i) taking safety measures for their own health against Coronavirus, (ii) managing the dairy cattle and preventing them, and (iii) selling their milk regularly with the usual price. Against this, milk price has decreased on one hand, and on the other hand, feed price has increased (IDRN 2020). This has further been aggravated by distorting the regular milk market channel causing a reduction to market access for selling the milk. To ameliorate this situation and as a measure of safeguarding dairy farmers, the government has taken the right decision to declare milk production, dairy farm-related activity (e.g., milk selling, feed supply, milk processing), and others related to dairying as emergency services and exempted from countrywide lockdown (public and private holiday and stop in all kind of public transportation). Even with such actions, it is obvious to face the economic shock not only due to the limited milk marketing channel but also because the consumers are more active in taking their own safety measures rather to have regular milk in their diet.

Due to the recent Coronavirus world pandemic problem, it also hit and affected millions of dairy farmers in Bangladesh. The Bangladesh government is trying to safeguard their farming activity, but the question might remain how and to what extent. At the same pace, the Sustainable Dairy Development (SDD) as a part of the Sustainable Development Goals (SDG) might need to be redefined while considering the impact of Coronavirus. The SDD and policy framework (Uddin et al. $2020 \mathrm{a}, \mathrm{b})$ and the previous forecasting for achieving selfsufficiency in 2030 in milk production (Uddin et al. 2020a, b) also need to be revised considering the real-time economic loss at the farm level.

\footnotetext{
${ }^{1}$ Estimated by Integrated Dairy Research Network (IDRN) using the Department of Livestock (DLS) 2018 data of 9.92 million tons of milk production. DLS is the legal entity working under the Ministry of Fisheries and Livestock for all kinds of regulation, extension, and technology transfer for livestock development.
}

It is very much early to get all precise data on the economic parameter and data are certainly anecdotal to make a very precise estimation. Until now, no organization could do the economic analysis considering the Coronavirus impact. The IDRN under the Department of Animal Nutrition of Bangladesh Agricultural University has the capacity to address such issues due to its strong database by monthly updating on dairy data (https://www.idrndairy.org/dairy-news), IDRN Farm Model, and having international collaboration to get access to the International Farm Comparison Network (IFCN) Farm Simulation Model (Hemme 2000; IFCN 2019; Richardson 1998), and is able to analyze the real-time facts and findings in farm economics. The economic analysis using the econometric approach has got criticism due to the fact that this type of analysis lacks addressing the real-time data (Hemme et al. 2014) while the IFCN Farm Simulation Model can take this advantages to integrate the realtime farm data and can produce the impact on the wider level (dairy farmers, processors, input suppliers, and policymakers).

The IDRN has felt mandate toward such initiatives and is expected to have a strong impact on identifying the real-time farm economic loss at the farm and dairy sector level which upon publishing would be helpful for the policymakers to take the right decision. On the other hand, dairy farmers and dairy processors will equally be benefitted from this analysis. Taking all of the facts into account, the IDRN takes this study with the objective to analyze the latest status quo of the dairy industry, to quantify the total financial loss incurred in the dairy industry due to Corona and how shall be the action plans for combating the crisis of the dairy farmers for making a way forward for millions of dairy farmers in the country.

\section{Methodology}

\section{Application of IFCN farm simulation model}

This study utilizes the concept of International Farm Comparison Network (IFCN) methodology developed by Hemme (2000) which is further refined and validated each year to update the model and increase its ability to take the real-time changes in the model (IFCN 2019). This method consists of three pillars: (i) typical farm approach (TFA), (ii) Technology Impact Policy Impact Calculations (TIPICAL) model, and (iii) the concept of dairy networking. We applied the TIPICAL model, which in principle have a similar impact to the Farm-Level Income and Policy Simulation Model (FLIPSIM) developed by Texas A\&M (Richardson 1998) but IFCN model has advantages over the FLIPSIM model in two areas:

(i) IFCN model has the capacity to integrate the macro-level changes of any input and output price to produce the impact changes in both in dairy sector (macro-level) and dairy farm (micro-level). 
(ii) IFCN model accommodates the real-time farm data and price changes and make results which are more up to date than the FLIPSIM. Thus, the IFCN Farm Simulation Approach is better in predicting the estimation of farm economic analysis

For estimating the economic loss at the farm level as a result of the COVID-19 infection in Bangladesh, the IFCN Farm Simulation Model was applied.

\section{Modeling the impact of input and output price changes on the farm economics}

\section{Selection of typical farm}

We selected two typical farms using the TFA approach of IFCN (Ndambi and Hemme 2008; Uddin et al. 2010; Hagemann et al. 2011; Hemme et al. 2014 and Sultana et al. 2014). The first typical farm is BD-2 cow, which represents the model farm (the most frequently occurring farm in a normal distribution curve) with herd size ranges from 1 to 3 cows. This is called a household farm (small farm $)^{2}$ and the second one, BD-14 cow, is the family farm (medium farm). The selection of BD-2 and BD-14 cows farms is based on the transect survey of 616 and 723 dairy farms with herd size ranging from 1 to 3 and 4 to 16 cows, respectively. The selected BD-2 cow (household farm) for this study represents $42 \%$ of the farm and BD-14 cow (family farm) represents $48 \%$ of the total farms in Bangladesh (IDRN 2020).

The descriptions of the typical farms, which were simulated for demonstrating the effect of Corona on the economics of the dairy sector, are shown in Table 1.

$B D-2$ is a typical household farm which has 2 dairy cows with 0.4 ha of land ( $10 \%$ for dairy) with milk production of $945 \mathrm{~kg} / \mathrm{cow} /$ year (natural content without any correction for fat and protein) and $2.59 \mathrm{~kg} / \mathrm{cow} /$ day with mostly family labor and no hired labor.

$B D-14$ is a typical family farm which as 14 dairy cows with 2.3 ha land (35\% land is allocated for dairy) with milk production of $1227 \mathrm{~kg} / \mathrm{cow} / \mathrm{year}$ (natural content without any correction for fat and protein) and $3.47 \mathrm{~kg} / \mathrm{cow} /$ day with a combination of both family and hired labor.

\footnotetext{
${ }^{2}$ IFCN farm classification approach has defined three types of dairy farms: (i) household farms, (ii) family farms and business farms. Household farm (HF) is defined as small farms; dairy is one of the income source for livelihoods, mainly consumed at household level, and surplus milk is sold. The herd size ranges from 1 to 3 cows (global standard: 1-30 cows). Family farm (FF) is defined as the medium farm; work is done mainly by family members, with a herd size from 4 to 16 (global standard: 31-300 cows). Business farm (BF) is defined as the large farm which operate their business based on return on investment (ROI) and work is done by mainly hired employee. The herd size $>16$ (global standard > 300). In this study, we analyzed the HF and FF (approximately $90 \%$ of the farm type in Bangladesh).
}

Typical farm represents the most common farming system which produces a significant proportion of milk in a country or region.

In the cross-farm comparison, milk is standardized to solid corrected milk (SCM) (IFCN 2019). The SCM is standardized to $4 \%$ fat and $3.3 \%$ protein which is calculated as

$\mathrm{SCM}=\frac{\text { Milk production } \times(\text { fat } \%+\text { true protein } \%)}{7.3}$

\section{Selection of simulation variables}

The five key simulating variables which were mostly affected due to Corona were used as a proxy for the effect of Corona (with Corona) for the month of March 2020 compared with the average changes in 2019 for predicting for the subsequent time in 2020 (from January to July) which are depicted in Table 2. However, due to the dynamic nature of the dairy sector, the data variability on monthly basis from January to July 2020 was used although results were mostly focused on March compared with the previous year.

These changes were applied to simulate the results which are considered as Coronavirus (COVID-19) effect. Using this farm data and applying the IFCN Farm Simulation Model by taking into account the variables change (Table 2), the IFCN typical model is simulated to quantify the loss of farm income by comparing with Corona and without Corona.

\section{Estimation of farm economic indicators}

To estimate the farm economic loss during the period of Coronavirus (COID-19) infection, we take the profit and loss account (P\&L accounts) of the typical farm (IFCN 2019). The $\mathrm{P} \& \mathrm{~L}$ is a model for estimating the output variables which are described below:

$$
\begin{aligned}
& \text { Entrepreneur's profit (USD/100 kg SCM) }: E_{\mathrm{p}} \\
& \quad=\mathrm{FI}_{\mathrm{dpx}}-\mathrm{OC}_{\mathrm{ln}}-\mathrm{OC}_{\mathrm{lna}}-\mathrm{OC}_{\mathrm{la}}-\mathrm{OC}_{\mathrm{cp}}-\mathrm{OC}_{\mathrm{qt}}
\end{aligned}
$$

where

$E_{\mathrm{p}} \quad$ The entrepreneur's profit (USD/100 kg SCM); and

$\mathrm{FI}_{\mathrm{dpx}} \quad$ Farm income excluding decoupled payments (USD/ $100 \mathrm{~kg} \mathrm{SCM}) ; \mathrm{OC}_{\mathrm{ln}}=$ The opportunity cost for own land (USD/100 kg SCM)

$\mathrm{OC}_{\text {lna }}$ The opportunity cost for land-alternative use (USD/ $100 \mathrm{~kg} \mathrm{SCM}$ )

$\mathrm{OC}_{\mathrm{la}}$ The opportunity cost for own labor (USD/100 kg SCM)

$\mathrm{OC}_{\mathrm{cp}}$ The opportunity cost for own capital (USD/100 kg SCM)

$\mathrm{OC}_{\mathrm{qt}}$ The opportunity cost for own quota (USD/100 kg $\mathrm{SCM})$. For Bangladesh's case, its own quota cost is zero. 
Table 1 Effect of Corona on the economics of the dairy sector. This table describes the key variables of the typical farms which are affected by Corona.

This table also showed the names of the farm with and without Corona along with the time frame

\begin{tabular}{llllll}
\hline Variables & \multicolumn{2}{l}{2019} & & \multicolumn{2}{l}{2020} \\
\cline { 2 - 3 } \cline { 5 - 6 } \cline { 5 - 6 } & Without Corona (WOC) & & With Corona (WC) \\
\hline Typical farm name & BD-2/19-WOC & BD-14/19-WOC & & BD-2/20-WC & BD-14/20-WC \\
Herd size & 2 & 14 & 2 & 14 \\
Data reference & 2019 & 2019 & & March 2020 & March 2020 \\
Milk yield (kg/cow/year) & 945 & 1265 & & 926 & 1227 \\
Land base (ha/farm) & 0.4 & 2.3 & & 0.4 & 2.3 \\
Labor & & & & 0.38 & 1.38 \\
Family labor (LU) & 0.38 & 1.38 & & 0 & 0.48 \\
Hired labor (LU) & 0 & 0.48 & &
\end{tabular}

$L U$, labor unit; 1 labor unit $=2100$ working hours $($ IFCN 2019)
Return over Investment (\%) : ROI $=\frac{A_{\mathrm{vc}}}{A_{\mathrm{v}}-A_{\mathrm{vc}}}+\frac{C_{\mathrm{r}}}{C_{\mathrm{i}}}$

ROI return over investment; and

$A_{\mathrm{vc}} \quad$ Change in asset value (USD/year)

$A_{\mathrm{v}} \quad$ Asset value (USD/year)

$C_{\mathrm{r}} \quad$ Return to capital including land and quota value (USD/ farm)

$C_{\mathrm{i}} \quad$ Capital input including land and quota (USD/farm)

Estimation of farm resilience The estimation of the farm resilience is expressed as liquidity (\%), operating profit margin, and financial performance. These are stated below:

Liquidity $(\%): L_{\mathrm{r}}$

$$
=\frac{\sum \mathrm{DR}_{\mathrm{c}}+\sum G_{\mathrm{p} / \mathrm{s}}+\sum \mathrm{RS}+\sum \mathrm{OR}}{\left(\mathrm{P} \& \mathrm{~L} \times \mathrm{MM}_{\mathrm{ot}} \times 10\right)-\left(\sum F_{\mathrm{d}}+\mathrm{DR}_{\mathrm{flc}}+\mathrm{DR}_{\mathrm{t}}+\mathrm{DR}_{\mathrm{lr}}\right)}
$$

where

\section{$L_{\mathrm{r}} \quad$ Liquidity}

$\sum \mathrm{DR}_{\mathrm{c}} \quad$ Sum current dairy receipts (USD/year)

$\sum G_{\mathrm{p} / \mathrm{s}} \quad$ Sum government payment/or subsidies (USD/year)

$\sum \mathrm{RS} \quad$ Sum return from shares (USD/year)

$\sum \mathrm{OR}$ Sum of other return (USD/year)

P \& L Cost P\&L (USD/100 kg SCM)

$\mathrm{MM}_{\mathrm{ot}} \quad$ Marketable milk output (tons/year) $\sum F_{\mathrm{d}} \quad$ Total farm depreciation (USD/year)

$\mathrm{DR}_{\mathrm{flc}} \quad$ Dairy related family living cost (USD/year)

$\mathrm{DR}_{\mathrm{t}} \quad$ Dairy related taxes (USD/year)

$\mathrm{DR}_{\mathrm{lr}} \quad$ Dairy related loan redemption (USD/year)

Operating profit margin $(\%): \mathrm{OP}_{\mathrm{m}}$

$$
=\frac{\left(\mathrm{FI}_{\mathrm{dpx}}+\mathrm{IL}+F_{\mathrm{t} \& \mathrm{~d}}+\sum F_{\mathrm{td}}+\sum \mathrm{OC}_{\mathrm{rp}}\right)}{\sum \mathrm{FR}-D_{\mathrm{p}}}
$$

where

$\mathrm{OP}_{\mathrm{m}} 5 \quad$ Operating profit margin, and

$\mathrm{FI}_{\mathrm{dpx}} \quad$ Farm income excluding decoupled payments (USD/ year)

IL Calculated interest for liabilities (USD/year)

$F_{\text {t \& d }} \quad$ Farm taxes and duties (USD/year)

$\sum F_{\mathrm{td}} \quad$ Total farm depreciation (USD/year)

$\sum \mathrm{OC}_{\mathrm{rp}} \quad$ Sum opportunity cost based on rent prices (USD/year)

$\sum F R \quad$ Total farm return (USD/year)

$D_{\mathrm{p}} \quad$ Decoupled payments (USD/year)

Financial performance $(\%): \mathrm{FP}_{\mathrm{df}}$

$$
=\frac{\mathrm{EP}_{\mathrm{dpx}}+D_{\mathrm{p}}}{\sum\left(L+B+M+M_{\mathrm{q}}+C_{\mathrm{s}}+F_{\mathrm{i}}+L_{\mathrm{c}}+S_{\mathrm{i}}+C_{\mathrm{h}}+O_{\mathrm{t}}\right)}
$$

Table 2 Simulating variables that have a strong impact on farm income of the typical dairy farms. This table explains the variables which are used for the Farm Simulation Model

\begin{tabular}{llllll}
\hline & March 2020 & April 2020 & May 2020 & June 2020 & July 2020 \\
\hline Milk yield & $-3.0 \%$ & $(-) 2.1 \%$ & $(-) 1.8 \%$ & $(-) 4.6 \%$ & $(-) 1.6 \%$ \\
Milk price & $-17 \%$ & $(+) 5.3 \%$ & $(-) 1.9 \%$ & $(-) 4.2 \%$ & $(+) 8.8 \%$ \\
Marketable milk & $(-) 4$ & $(-) 4$ & $(-) 4$ & $(-) 4$ & $(-) 4$ \\
Milk wastage & $(-) 5$ & $(-) 5$ & $(-) 5$ & $(-) 5$ & $(-) 5$ \\
Feed price & $(+) 3.7$ & $(+) 1.4 \%$ & $(+) 0.1 \%$ & $(+) 1.5 \%$ & $(-) 2.8 \%$ \\
\hline
\end{tabular}

Changes are presented for March and onward 2020 compared with an average of 2019 (source: IFCN 2019 and IDRN 2020); “+” indicates increase and "_" indicates a decrease 
Where,

$\mathrm{FP}_{\mathrm{df}} \quad$ Financial performance of dairy farms; and

$\mathrm{EP}_{\mathrm{dpx}} \quad$ Entrepreneurs profit (EP) excluding decoupled payments (USD/100 kg SCM)

$D_{\mathrm{p}} \quad$ Decoupled payments (USD/100 kg SCM)

$L \quad$ Land

$B \quad$ Building

$M \quad$ Machinery

$M_{\mathrm{q}} \quad$ Milk quota

$C_{\mathrm{s}} \quad$ Shares of the cooperatives

$F_{\mathrm{i}} \quad$ Field inventory

$L_{\mathrm{c}} \quad$ Livestock

$S_{\mathrm{i}} \quad$ Storage input

$C_{\mathrm{h}} \quad$ Cash on hand

$O_{\mathrm{t}} \quad$ Other

Farm Income $(\mathrm{BDT} /$ year/farm $): F_{\mathrm{i}}$

$$
=\left\{\left(\sum \mathrm{TF}_{\mathrm{r}}-\sum \mathrm{TF}_{\mathrm{i}}+V_{\mathrm{b}}-D_{\mathrm{p}}\right) \times\left(\mathrm{MM}_{\mathrm{p}} \times \mathrm{CF}\right) \times 10\right\}
$$

$F_{\mathrm{i}} \quad$ Farm income (USD/farm); and

$\sum \mathrm{TF}$ Total farm return (USD/100 kg SCM);

$\sum \mathrm{TF}_{\mathrm{i}}$ Total farm input (USD/100 kg SCM);

$V_{\mathrm{b}} \quad$ Vat balance (USD/100 kg SCM) - decoupled payment (USD/100 kg SCM);

$\mathrm{MM}_{\mathrm{p}} \quad$ Production of marketable milk;

CF $\quad$ SCM correction factor $(4 \%, 3.3 \%)$

The data was taken from five sources: (i) IFCN dairy sector data (IFCN 2019), (ii) IDRN, dairy sector, and dairy farm database (IDRN 2020), (iii) DLS annual data on livestock (DLS 2019), (iv) online source of COVID-19 data (www. worldometers.info), and (v) conversion factor for BDT to USD (conversation date: August 31, 2020) from Bangladesh Bank which is adjusted from www.oanda.com. Data was analyzed using MS Excel 365 and TIPICAL software version 5.6.

\section{Results and discussions}

\section{Effect on a dairy farm}

\section{Effect on milk yield and cost of milk production only in the typical dairy farms}

The effect of Coronavirus on milk yield and cost of milk production in BD-2 cow and BD-14 cow farm is depicted in Fig. 1a, b, respectively. The milk production (Fig. 1a) is found to be decreased from $948 \mathrm{~kg} \mathrm{SCM} / \mathrm{cow} /$ year (BD-2/19-WOC) to $883 \mathrm{~kg} \mathrm{SCM} / \mathrm{cow} /$ year (BD-2/20-WC). For large farms, the milk yield is decreased from $1218 \mathrm{~kg} \mathrm{SCM} /$ cow/year (BD-14/19-
WOC) to $1122 \mathrm{~kg} \mathrm{SCM} / \mathrm{cow} /$ year (BD-14/20-WC). Translating this decrease to per cow per day, it is found that milk yield is decreased from $2.60 \mathrm{~kg} \mathrm{SCM} / \mathrm{cow}$ (BD-2/19-WOC) to $3.34 \mathrm{~kg} \mathrm{SCM} / \mathrm{cow} /$ day (BD-2/20-WC) which is corresponding to a $7.9 \%$ decrease while that for the large farm, the milk yield is decreased from $3.34 \mathrm{~kg} \mathrm{SCM} / \mathrm{cow} /$ day (BD-14/19-WOC) to $3.08 \mathrm{~kg} \mathrm{SCM}$ (BD-14/20-WC) that is corresponding to $8.9 \%$ decrease during Corona time compared with before Corona. The average production in a typical farm is somewhat lower than the survey-based econometric findings on the average of small, medium, and large farm milk yield per day (Datta et al. 2018).

The cost of milk production is the key to make a profit margin. Globally, higher milk price is argued as the major driver for spreading profit margin. Since the milk price is external and beyond the farmer's intervention, it is rather important to focus on decreasing the cost of milk production which in turn increases the profit margin (Hemme et al. 2014). Among several managerial issues to combat Coronavirus, it is highly relevant to analyze the cost of milk production. The cost of milk production is highly influenced by the input price changes, especially the feed price which is the major driver for increasing cost in the dairy farms (Hemme et al. 2014; Ndambi and Hemme 2008). With Corona as an effect on the decreasing milk yield (Fig. 1a) and increasing feed price (Table 2), it is quite obvious that the cost of milk production only (COMPO) is increased in both small farm (BD-2/20-WC) and large farm (BD-14/20-WC) which is depicted in Fig. 1b.

The average cost of milk production for both farms is increased by $15 \%$ during the period of Corona but the increase varies depending on the scale of the production. The cost is increased by $0.10 \mathrm{USD} / \mathrm{kg}(8 \mathrm{BDT} / \mathrm{kg})$ in BD- $2 / 20-\mathrm{WC}$ and $0.04 \mathrm{USD} / \mathrm{kg}(3.5 \mathrm{BDT} / \mathrm{kg})$ in BD-14/20WC, which corresponds to $19.10 \%$ and $10.9 \%$, respectively, for household and family farms. The key drivers for the cost increase were associated with an increase in feed price and a decrease in milk production, transportation problem, and panic in buying animal products.

The COMPO has two important cost items, cash costs and opportunity costs. The higher cash costs of the farm means, farmers need to pay cash for inputs and other services which might decrease the cash flow of the farms. The decreased cash flow was associated with the reduction in the return to labor in dairy. The proportion of costs and return to labor is depicted in Fig. 2a and Fig. 2b.

Figure 2a shows that cash costs increased due to Corona by $4 \%$ (from 58 to $62 \%$ ) in household farms (BD-2/20-WC) while for the family farm (BD-14/20WC) by $1 \%$ (76 to $77 \%$ ). The higher costs ended up with less cash flow for paying the salary of the dairy farmers. Figure $2 b$ shows that without Corona, the household farm (BD-2/20-WC) was not able to pay the competitive salary as the dairy workers can earn $0.71 \mathrm{USD} / \mathrm{h}(60 \mathrm{BDT} / \mathrm{h})$ in the alternative sector than by working in dairy $0.52 \mathrm{USD} / \mathrm{h}(44.0 \mathrm{BDT} / \mathrm{h})$. Corona has made 
Fig. 1 a Effect of Corona on milk yield in typical dairy farms. This figure describes the milk yield and the effects of Coronavirus on milk yield change. $\mathbf{b}$ Effect of Corona on the cost of milk production only in typical dairy farms. This figure describes the cost of milk production with and without Corona

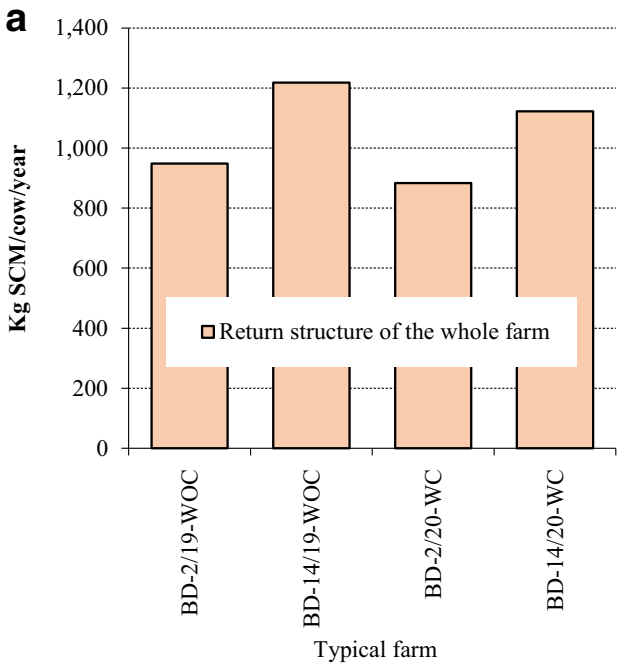

this further decreased, indicating a decrease in salary in dairy per hour is $0.35 \mathrm{USD} / \mathrm{h}(29.8 \mathrm{BDT} / \mathrm{h})$ for BD-2/20-WC which is $32 \%$ lower than before Corona, which implies that with Corona, the labor competitiveness is further worsened. But before Corona, the family farm (BD-14/20-WOC) is competitive while after Corona, the same farm (BD-14/20-WC) lost its labor competitiveness as the dairy farm worker is paid 0.31 $\mathrm{USD} / \mathrm{h}(26.5 \mathrm{BDT} / \mathrm{h})$ which is $57 \%$ lower than before Corona.

If this is not resumed, dairy farm owner either has to pay off the worker with regional competitive level from using the surplus money or taking any loan or has to decrease the production volume to reduce labor use.

\section{Effect of Corona on entrepreneur's profit and return on investment of dairy farms}

The entrepreneur's profit (EP) is estimated by deducting the costs for all inputs and opportunity costs while just profit is estimated by deducting the costs for all input from the return. The entrepreneur's profit is the profit by which the farmers can get their salary for their own family labor, own land, and own capital. On the other hand, the return on investment (ROI) explains the capital competitiveness of the dairy investment. The EP $>0$ is considered as economically sustainable dairy production and at the same pace, if the ROI > bank interest rate for deposit leads to more investment in dairy. The EP and ROI of the typical farm are depicted in Fig. 3a and b. With the increased feed price, higher cost of milk production especially with cash costs, the entrepreneur's profit is decreased substantially for household and family farms. Before Corona, the household farm (BD-2/19-WOC) had a negative profit; for each kilogram of milk production, the farm was losing $0.10 \mathrm{USD} / \mathrm{kg}$ (8.21 taka/kg) while the family farm (BD-14/19-WOC) had a positive profit of $0.03 \mathrm{USD} / \mathrm{kg}(2.65 \mathrm{taka} / \mathrm{kg}) \mathrm{milk}$ production.
Fig. 2 a Proportion of cash costs on total costs. This figure describes the cash cost amount on total cost items of the dairy farms. b Effect of Corona on labor competitiveness in a typical farm. This figure describes the change in labor competitiveness due to Coronavirus

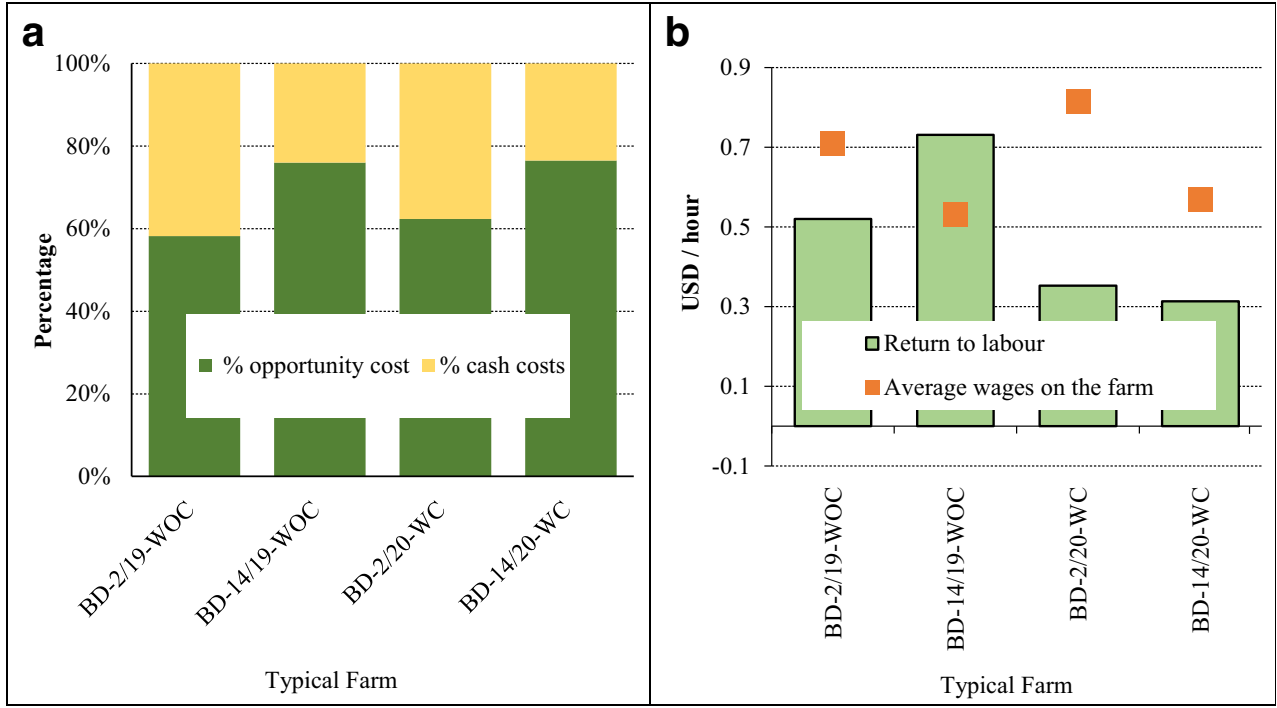


Fig. 3 a Entrepreneurs profit of dairy farms. This figure describes the entrepreneur's profit (EP) of the dairy farms and the change in EP due to the effect of Coronavirus. b Return on investment. This figure describes the return on investment with and without Coronavirus

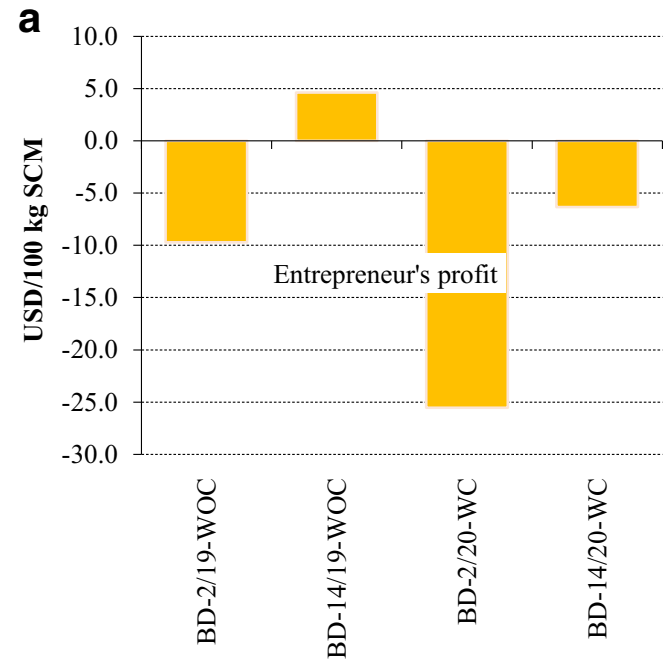

Typical Farm

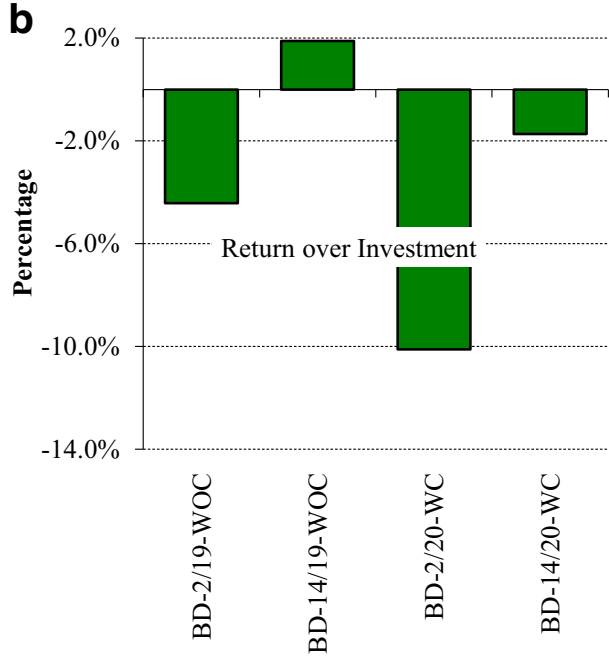

Typical Farm
The ROI of the household farm (BD-2/19-WOC) and family farm (BD-14/19-WOC) were found $-4.4 \%$ and $+1.9 \%$, respectively. The current interest rate of deposit (nominal) of $6 \%$ is far higher than the return from dairy. Given the estimation of EP and ROI considering the Corona effect, it is evident that both the household farm (BD-2/20-WC) and family farm (BD-14/20-WC) fall under serious loss in EP and ROI, indicating the lack of sustainability and facing difficulties to get the bank loans with $9 \%$ interest.

The EP for a household farm (BD-2/20-WC) is -0.26 $\mathrm{USD} / \mathrm{kg}(-21.56 \mathrm{BDT} / \mathrm{kg})$ milk while for the family farm (BD-14/20-WOC) is $-0.06 \mathrm{USD} / \mathrm{kg}(-5.39 \mathrm{BDT} / \mathrm{kg}) \mathrm{milk}$. The same trend is for the ROI, where the household farm (BD$2 / 20-$ WC) and family farm (BD-14/20-WOC) were $-10.1 \%$ and $-1.7 \%$, respectively.

\section{Effect of Corona on resilience of the typical farm}

Corona has a substantial effect on the financial resilience of the typical farms which are depicted in Fig. 4a, b, and c. The dairy farm resilience is a function of liquidity (\%) on cash flow, operating profit margin (\%), and financial performance (\%). Each of them has been defined as a boundary of the resilience, so-called farm resilience corridor which are $20 \%$, $10 \%$, and $5 \%$ for liquidity, operating profit margin, and financial performance, respectively. The liquidity is calculated as the total cash receipts over total cash expenses, while the financial performance is calculated as the EP over the total farm asset, and operating profit margin is calculated as the deduction of the operating costs from operating receipts.

Figure $4 \mathrm{a}$ shows that due to Corona, liquidity of the household typical farm (BD-2/20-WC) and family typical farm (BD$14 / 20$-WC) is decreased from $97 \%$ to $17 \%$ and $101 \%$ to $83 \%$, respectively. The liquidity of $120 \%$ is assumed to be a good reflection of the financial stability as the farm always needs a
$20 \%$ surplus cash flow for mitigating any unexpected crisis (like the present crisis of COVID-19). Corona is one of the negative impacts which is unforeseen and none of the dairy value chain stakeholders could predict upfront. Since the household farm has been suffering from the lack of cash flow, supporting the household farmers is urgently urged. Similar issues are also observed for family farms where the decrease in liquidity is even much lower, which implies that the farm will continue to face the tremendous financial crisis unless any interventions are made. Figure $4 \mathrm{~b}$ shows that before Corona hit, household farm (BD-2/19-WOC) has an operating profit margin of $-5 \%$ and that of the family farm (BD-14/19-WOC) is + $17 \%$ which was further decreased to $-30 \%$ for the household farm (BD-2/20-WC) and $+1 \%$ for family farm (BD-14/20$\mathrm{WC})$. Figure $4 \mathrm{c}$ shows a decline in financial performance for the household farm (BD-2/19-WC) from -4 to $-9 \%$ while for the family farm (BD-14/20-WC), this has turned from positive $(+5 \%)$ to negative $(-2 \%)$.

The operating profit margin of $10 \%$ is considered for sustainable operation of the dairy business in which, however, our study revealed that due to Corona, none of the farms has a $10 \%$ profit margin, rather with a negative profit margin (from Fig. 4b) falls under threat for continuing dairy business. Finally, the resilience of the financial performance is $+5 \%$ is considered for good buffering capacity for dairy farm. The same is applicable for the financial performance which was decreased due to Corona. This again implies that farmers need financial intervention to raise their resilience capacity to combat Corona and similar other types of exogenous shock.

\section{Effect of Corona on farm income and overall loss of the dairy farmers in Bangladesh}

Considering the dairy sector changes and impact on farm profit, the overall loss in the dairy farm level is estimated. 
a

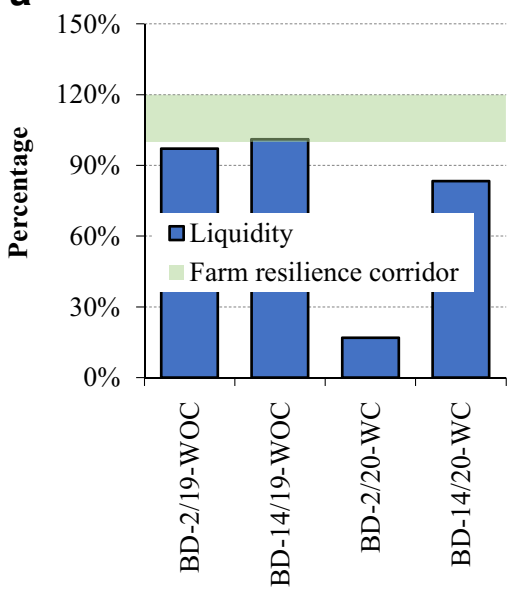

Typical farm

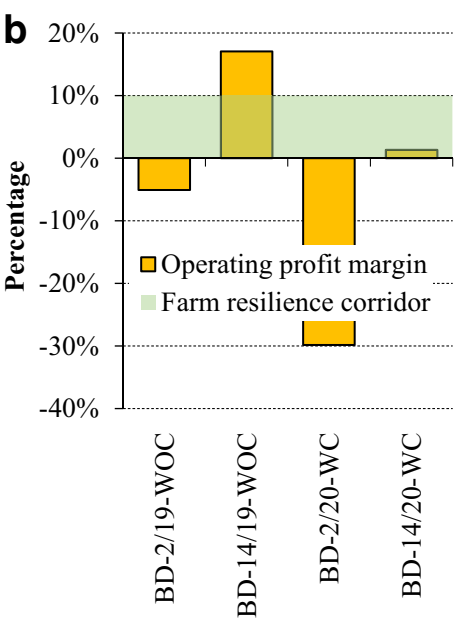

Typical farm

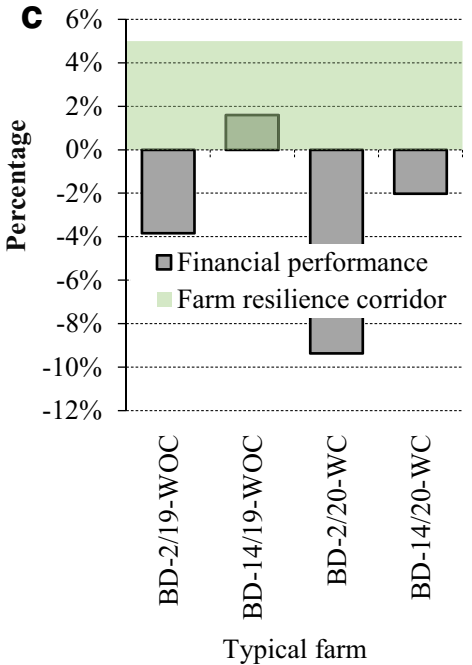

Typical farm
Fig. 4 a Liquidity of dairy farms. This figure describes the resilience of dairy farms based on liquidity. b Buffer capacity: operating profit margin. This figure describes the resilience of dairy farms considering the operating profit margin. c Financial performance of dairy farms. This figure describes the resilience of dairy farms due to the change in financial performance

Similar is found in farm income to turnover and net cash farm income. The overall effect is that each household farm (BD-2/20-WC) loses $56.45 \mathrm{USD} /$ month (4776 BDT/month) and for each family farm (BD-14/20-WC) is $139.641 \mathrm{USD} /$ month (11,815 BDT/month). Estimation of the total loss of the dairy farmers in Bangladesh is 4.43 million USD/day (36.84 crore BDT/day) wherein the household farms (BD-2/20-WC) lose 1.18 million USD/day and family farms (BD-14/20-WC) lose 3.25 million USD/day.

However, due to the dynamic nature of the dairy sector, a continuation of the pandemic COVID-19 (Corona), the economic loss has been extended until July 2020. This could be extrapolated for similar other cases where it can be replicated in a sense that the decrease in milk price and increase in feed price was the key feature of the Corona-induced effect. The effect of this is shown in Fig. 5a and b which shows that the

Table 3 Effect of Corona on farm income and economic loss of dominating dairy farms in Bangladesh. This table shows the estimation of the economic loss of the dairy farmer- and national-level loss

\begin{tabular}{|c|c|c|c|c|c|}
\hline Farm profit & Unit & BD-2/19-WOC & BD-14/19-WOC & BD-2/20-WC & BD-14/20-WC \\
\hline Farm income & USD/year & 276.61 & 2668.63 & -400.69 & 992.92 \\
\hline Farm income to turnover & $\%$ & $0.18 \%$ & $0.26 \%$ & $-0.34 \%$ & $0.11 \%$ \\
\hline Net cash farm income & USD/year & 288.43 & 2810.46 & -388.88 & 1134.75 \\
\hline Decrease in farm income & USD/month/farm & - & - & 56.45 & 139.64 \\
\hline Total loss & USD/day/farm & - & - & 1.88 & 4.66 \\
\hline Total loss & USD/day/cow & & & 0.94 & 0.33 \\
\hline Total loss in $\mathrm{BD}$ & USD in million/day & - & - & 1.18 & 3.25 \\
\hline Grand total & Million USD /day & 4.43 & & & \\
\hline
\end{tabular}

Total dairy farmers in BD: 1.44 million of which (42\% small farms-BD-2, and 48\% large farms-BD-14)

Source: IFCN 2019 and IDRN 2019 
Fig. 5 a, b Total loss of dairy industry during the COVID-19 period, This figure explains the loss that incurred in the dairy industry during the COVID-19 period from March 2020 to July 2020 after its outbreak 8 th March 2020

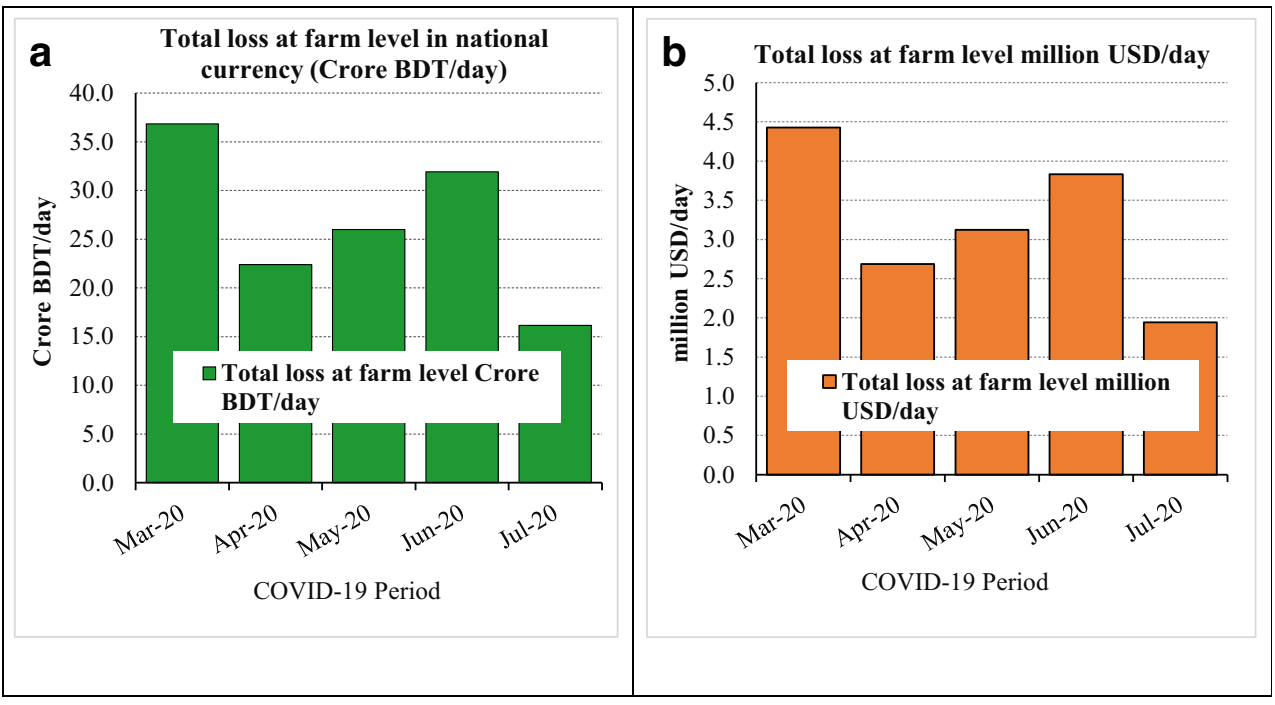

highest economic loss was obtained at the beginning of Corona (March 2020).

As a rapid step taken by the government on intervention on the dairy production, processing, and marketing, the loss was decreased in April 2020 (2.69 million USD/day) but the loss was increasing in May (3.12 million USD/day) and June (3.83 million USD/day) as the milk production was decreasing due to a combination of the COVID-19, flood (a natural disaster) and usual seasonality in milk production. The economic loss was observed the lowest in July 2020 (1.94 million USD/day) due to the decreasing feed price (Table 2). The feed price decrease was due to the liberalization of feed import tariff of major feed ingredients like corn (all types of import duty $0 \%$ ) and soybean meal (regulatory duty was reduced from 5 to $0 \%$ ).

\section{Strategic action plan and way forward}

To combat the current and anticipated future economic loss in dairy farming owing to the Coronavirus infection has been a key agenda for all dairy stakeholders including the government. The importance of using farm costs, farm income changes, and milk and feed price ratio changes are useful policy instruments as the policymakers can decide to what extent the farmers should be supported (Uddin et al. 2017). This decision process plays a role not only during the Corona period but also even after Corona.

Taking the speed of the Coronavirus infection at a global level, it is evident that the USA which is a very big player and major exporting dairy country in the world has been in the frontier and ranked 1 in the Corona infection in terms of daily new cases (WHO 2020). On the other hand, India and China have a big impact on dairy production, consumption, and import and export market which are also affected by Corona. This implies that there will certainly be a negative impact on national and international trades in relation to dairy during and even after ending the Corona crisis.

Table 4 shows that total milk production globally is 887 million tons in 2019, of which the top 14 countries which are analyzed here produce 547.6 million tons corresponding to $61.7 \%$ of the total milk production (IFCN 2019). This implies that the world trade on dairy import and export is expected to be a negative balance causing a price hike in both liquid and imported milk in the subsequent time. Since Bangladesh is a net importing country, it will be affected by the shortage in the global market. Furthermore, to achieve self-sufficiency, Bangladesh needs a decade (Uddin et al. 2020a, b); the government has to consider both short- and long-term plans by considering global market shock on dairy trade.

Since milk price and feed price are the most volatile among all agricultural products, it is very much important to monitor the dairy market development as well as to monitor the farmlevel profitability. Figure 6 indicates the impact of Coronavirus to milk price and feed price at Bangladesh and the global level.

Figure 6 shows that after a milk quality shock in the second half of 2019, the milk price in Bangladesh started to increase which is $0.52 \mathrm{USD} / \mathrm{kg}$ (43.79 BDT/ $\mathrm{kg}$ ) in 2019 and 0.54 USD/kg (45.09 BDT/kg) in January 2020 (IDRN 2020). Though Coronavirus did not hit Bangladesh in February 2020, the milk price has fallen in February 2020 compared to January 2020, which might be due to the result of global Coronavirus impact.

For a profitable dairy, the milk price and feed price ratio is considered as $\geq 1.5$ which implies that the farm-level profitability for Bangladesh was at marginal level in February 2020 which shifted to negative return due to the sudden hit by Coronavirus (COVID-19). The milk price and feed price ratio also started to decline in Bangladesh from January 2020 which was 1.59 to 1.35 at the end of March 2020. Looking 
Table 4 Relation between milk production and COVID-19 prevalence. This table shows that Corona affected country and milk-producing country

\begin{tabular}{|c|c|c|c|c|c|}
\hline \multirow[t]{2}{*}{ Country } & \multirow{2}{*}{$\begin{array}{l}\text { Milk production } \\
\text { (mil. tons) }\end{array}$} & \multicolumn{3}{|c|}{ Total milk production (SCM, mil. tons) } & \multirow[b]{2}{*}{$\begin{array}{l}\text { Have an impact to } \\
\text { the world market }\end{array}$} \\
\hline & & $\begin{array}{l}\text { Rank_milk } \\
\text { production }\end{array}$ & $\begin{array}{l}\text { Rank_COVID- } \\
19\end{array}$ & Export/import* & \\
\hline India & 201.22 & 1 & 9 & +- & $\mathrm{Y}$ \\
\hline USA & 95.31 & 2 & 1 & + & $\mathrm{Y}$ \\
\hline Pakistan & 48.36 & 3 & 11 & +- & $\mathrm{Y}$ \\
\hline Brazil & 33.14 & 4 & 7 & + & $\mathrm{Y}$ \\
\hline Germany & 33.14 & 5 & 4 & + & $\mathrm{Y}$ \\
\hline China & 29.37 & 6 & 8 & - & $\mathrm{Y}$ \\
\hline New Zealand & 25.19 & 7 & 13 & + & $\mathrm{Y}$ \\
\hline France & 24.78 & 8 & 5 & + & $\mathrm{Y}$ \\
\hline Italy & 12.65 & 14 & 3 & + & $\mathrm{Y}$ \\
\hline Argentina & 9.99 & 17 & 12 & + & $\mathrm{Y}$ \\
\hline Australia & 9.56 & 19 & 10 & + & Y \\
\hline Iran & 10.05 & 20 & 6 & - & $\mathrm{Y}$ \\
\hline Bangladesh & $8.24 *$ & 23 & 14 & - & $\mathrm{N}$ \\
\hline Spain & 6.6 & 28 & 2 & + & $\mathrm{N}$ \\
\hline Total & 547.6 & & & & \\
\hline World & 887 & & & & \\
\hline$\%$ affected & $61.74 \%$ & & & & \\
\hline
\end{tabular}

$+=$ net export country; $-=$ net importing country; $Y$; yes; $N$; no

*IDRN data, according to DLS, milk production is 9.92 million tons

Source: IFCN 2019 and IDRN 2020 into the time series analysis, it is seen that the month of June 2020 was the lowest for milk and feed price ratio (1.35) which is translated to a decrease in farm income and an increase in farm loss. However, the global-level ratio might be predicted for variability which is still difficult to make a precise estimation. This implies that the Bangladesh government needs to take strategies that might support to reduce the feed price in their Corona-initiated action plan.
The findings of this study are expected to be benefitted from the current government's strategy to combat the COVID-19 and support the dairy farmers as a short-, medium-, and long-term Corona management for leading the country way forward. Realizing this, the Bangladesh government has been implementing "COVID-19 support program" to reduce the loss of the dairy farmers to restore the economic transmission. The results of the current study have clearly
Fig. 6 Comparing Bangladesh and global dairy market development with and without Corona. MF, milk price; FP, feed price; MP:FP, milk price and feed price ratio; $\mathrm{BD}$, Bangladesh. Comparing Bangladesh and global dairy market development with and without Corona. This figure describes a comprehensive indicator to benchmark the Bangladesh dairy market development to the global dairy market development considering the effect of Corona

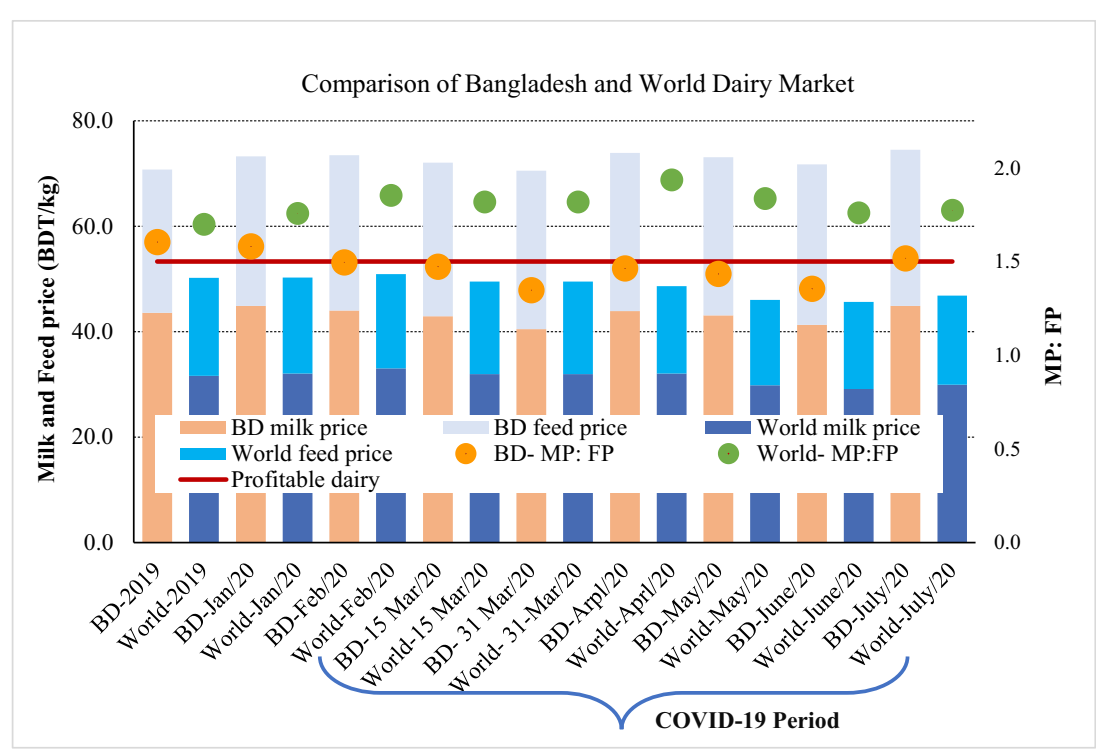


Fig. 7 Action plane framework to combat Corona-induced crisis.

This figure describes the possible options to combat Coronainduced crisis by involving all the stakeholders related to dairy like farmers, consumers, processors, research organization, government, and universities

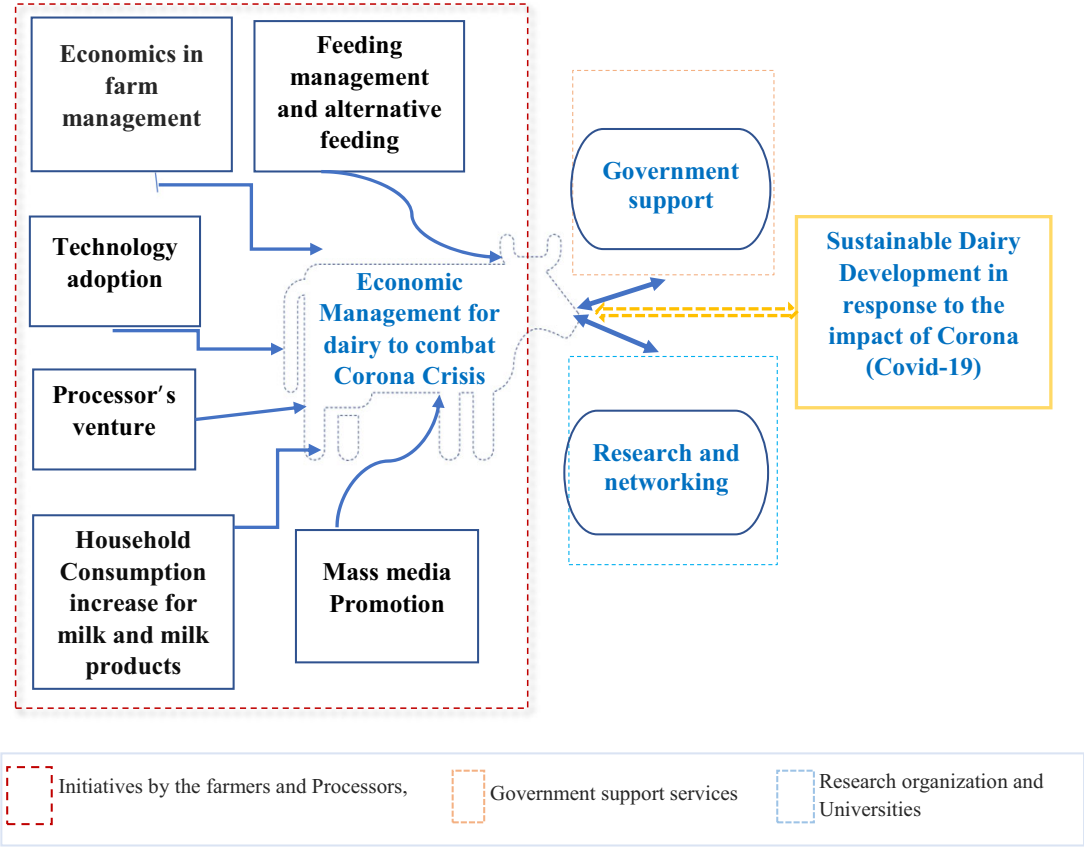

identified that the infection of Coronavirus might continue further although it is not possible to forecast for how long and what level of impact. Whatever the time horizon and impact intensity be, the economic loss which has already been happening might be going to increase to a greater extent leading to the greater loss of the dairy industry.

The extent of the loss in the dairy industry will be further increased as a result of overall global and local economic loss at the macro level. Immediate reaction from the government is to make short-term crisis management which has already been in the implementation process while the medium- to long-term strategies might need to be taken. To overcome the challenges arising from the crisis, all the stakeholders might have to take their own responsibility while the government can act as a mediator and provide all kinds of legal and regulatory actions. Multi-stakeholder's participation (e.g., dairy farmers, processors, input suppliers and companies, farmers' association, university and research organization, policymakers, and donor agencies) in the development of a strategic framework for addressing the impact of Coronavirus is necessary. A number of options with possible implementation strategies ${ }^{3}$ are proposed which are depicted in Fig. 7*.

The strategic action plan which entails holistic and multistakeholder participation where participation of the government is the starting point. At the same time, all other stakeholders also have relatively equal and responsible actions to combat Corona shock in the short and long term. The

\footnotetext{
3 This is the outcome by utilizing the current study results and the IDRN stakeholder's and expert opinion, due to the current emergency situations in relation to the Coronavirus, where the information is scanty, and this would fit the government's priority on to the developing strategy for saving millions of farmers.
}

Sustainable Dairy Development as one of the pillars of the Sustainable Development Goals (SDG) has to be redefined in order to address the impact of COVID-19. The processors might take the lead in increasing the investment for technology adoption at farm level for processing liquid milk, increase household consumption and intervention on dissemination on increasing farm economic knowledge and efficiency in feed management for reducing the cost of milk production. The mass media (electronic and printed) can also work in promoting the beneficial aspects of milk consumption for increasing the immunity to combat the COVID-19 virus infection and inspiring the farmers and policymakers for making congenial policy.

At the same pace, research and dairy networking can foster the real-time dairy data, knowledge creation, and bringing all the stakeholders in a common platform. The leading research organizations, university, and dairy networks such as IDRN could work together to make strategic decisions for combating the impact of COVID-19 at the farm level to reduce economic loss.

\section{Conclusions}

Utilizing the IDRN dairy sector model, it was revealed that during the Coronavirus infection period, the milk price is decreased by $-17 \%$ and feed price is increased by $+3.7 \%$. Milk yield decreased in the small farm from $2.60 \mathrm{~kg} \mathrm{SCM} / \mathrm{cow} /$ day to $2.42 \mathrm{~kg} \mathrm{SCM} / \mathrm{cow} / \mathrm{day}, 7.9 \%$ lower than that before Corona. On the other hand, this decrease in a large farm is from 3.34 to $3.08 \mathrm{~kg} \mathrm{SCM} / \mathrm{cow} /$ day, an $8.9 \%$ decrease due to Corona. Applying Farm Simulation Modeling and using this 
price change impact during the period of Coronavirus (COVID-19) infection, a negative farm income is observed, which is translated to the estimated overall economic loss per day accounting for 4.43 million USD (36.84 crore BDT). The cost of milk production is increased for small farms by $19.10 \%$ and large farms by $10.9 \%$. Return to labor (e.g., wages paid by the dairy farm compared with alternative wage rate) is decreased by $29 \%$ in small farms and $57 \%$ in large farms. The farm has cash flow problems, liquidity, and loss of the buffer capacity which if combined with a lower return on investment (ROI) clearly reveals that farmers need immediate cash support with less than $1 \%$ interest at the farm level.

Based on these results, a strategic option is developed and proposed to the government, which once the government considers could help dairy farmers to overcome the loss of Coronavirus (COVID-19). At the same time, farmers would be benefitted once the results are used by the farms. Finally, our analysis might be used by the government as a point of intervention for financial support especially to which type of farmers and how much might be supported.

\section{Compliance with ethical standards}

Statement of human and animal rights This research mainly deals with the data, models, and software. Primary data were generated from the dairy farmers but not used as an experimental unit. While working with dairy farmers and other stakeholders, human rights are preserved.

Conflict of interest The authors declare that they have no conflict of interest.

Disclaimer In case of any conflict arises, the publisher is no more responsible.

\section{References}

Datta, A.K., Haider, M.Z. and Ghosh, S.K. 2018. Economic analysis of dairy farming in Bangladesh. Tropical Animal Health and Production, 51: 55-64. https://www.ncbi.nlm.nih.gov/pubmed/ 30003526

DLS. 2019. Department of Livestock Services, Livestock Economy at a glance, Livestock Economic Division, Department of Livestock Services, Dhaka. http://www.dls.gov.bd/site/page/22b1143b-932344f8-bfd8-647087828c9b/Livestock-Economy

Hagemann, M., Hemme, T., Ndambi, A., Alqaisi, O. and Sultana, M.M. 2011. Benchmarking of greenhouse gas emissions of bovine milk production systems for 38 countries. Animal Feed Science and Technology, 166-167: 46-58

Hemme, T. 2000. Ein Konzept zur international vergleichnden Analyse von Politik-und Technikfolgen in der Landwirtschaft. LandbauforshungVölkernode, Sonderheft 215 (2000).
Hemme, T., Uddin, M.M. and Ndambi, O.A. 2014. Benchmarking cost of milk production in 46 countries. Journal of Reviews on Global Economics, 3: 254 -270. https://www.lifescienceglobal.com/pms/ index.php/jrge/article/view/1977

IDRN, 2019. Integrated Dairy Research Network. Monthly dairy sector update, Bangladesh Agricultural University, Bangladesh. Available at: www.idrn-dairy.org

IDRN, 2020. Integrated Dairy Research Network. Monthly dairy sector update, Bangladesh Agricultural University, Bangladesh. Available at: www.idrn-dairy.org

IFCN, 2019. Dairy Report for better understanding of milk production worldwide. IFCN-the Dairy Research Network, University of Kiel, Germany. www.ifcndairy.org

Ndambi, O.A. and Hemme, T. 2008. An economic comparison of typical dairy farming systems in South Africa, Morocco, Uganda and Cameroon. Tropical Animal Health and Production, 41(6): 979994. https://europepmc.org/article/med/19082756

Richardson, J.W. 1998. Simulation: A tool for decision making. Department of Agricultural Economics, Texas A\&M University, Education paper for simulation class.

Sultana, M.N., Uddin, M.M., Riddout, B.G. and Peters, K.J. 2014. Comparison of water use in global milk production for different typical farms. Agricultural Systems, 129: 9-21. https://www. sciencedirect.com/science/article/abs/pii/S0308521X14000523

Uddin, M.M., Sultana, M.N., Ndambi, O.A., Hemme, T. and Peters, K.J. 2010. A Farm Economic Analysis in different Dairy Production Systems in Bangladesh. Livestock Research for Rural Development, 22 (7) 2010, available at: http://www.lrrd.org/ lrrd22/7/uddi22122.htm

Uddin, M.M., Hemme, T., Ndambi, O.A., Sultana, M.N. and Khan, M.J. 2017. Impact of dairy support services and strategies on reduction of cost of milk production in different dairy production systems in Bangladesh: Implications for rural livelihood improvement. Asian Journal of Poverty Studies, 3(2): $95-104$.

Uddin, M.M., Akter, A., Khaleduzzaman, A. B. M. and Sultana, M.N. 2020a. Forecasting milk production in Bangladesh toward achieving self-sufficiency. Livestock Research for Rural Development, 32 (5) 2020, available at: $\mathrm{http}: / / \mathrm{www} .1 \mathrm{rrd}$. org//rrd32/5/moham32081.html

Uddin, M.M., Khaleduzzaman, A.B.M. and Akter, A. 2020b. Sustainable dairying and self-sufficiency in quality milk production in Bangladesh: the role of policy and a way forward. Bangladesh Journal of Academy of Science (Submitted).

WHO, 2020. World Health Organization, Daily Corona situation report. https://www.who.int/docs/default-source/coronaviruse/situationreports/20200418-sitrep-89-covid-19.pdf?sfvrsn=3643dd38_2

This research work has been taken as a responsibility of the IDRN Network to support the dairy industry of Bangladesh by providing the knowledge, facts, and real-time farm economic results in such global pandemic, COVID-19. The data are validated by local key dairy stakeholders which is the requirement of the Farm Simulation Model of IFCN. This paper is neither submitted nor published nor under review for possible publication.

Publisher's note Springer Nature remains neutral with regard to jurisdictional claims in published maps and institutional affiliations. 